\title{
The Development of Higher Education in China and Malaysia: A Comparative Perspective
}

\author{
Chen Li \\ School of Education Science, Liupanshui Normal University, Liupanshui, China
}

Email address:

chenli1@nbu.edu.cn

To cite this article:

Chen Li. The Development of Higher Education in China and Malaysia: A Comparative Perspective. Science Journal of Education. Vol. 9, No. 3, 2021, pp. 77-86. doi: 10.11648/j.sjedu.20210903.12

Received: April 20, 2021; Accepted: May 19, 2021; Published: May 24, 2021

\begin{abstract}
Since the 1990s, higher education in the developing countries has gone through great changes in response to their fundamental political and socio-economic reforms. China and Malaysia, the two main Asian developing countries with emerging economies and ambitious goals, were picked up for a comparison of higher education development to better illustrate this general trend. In this comparative framework, comparability about the two countries is analyzed firstly, followed by the consideration of three key dimensions, and George Bereday's method of comparison is accordingly used. It is noted from the comparison that both Chinese and Malaysian higher education systems have experienced massification, marketization and internationalization, and are currently striding toward universalization with more excellence-driven initiatives of higher education, which involve the main mechanisms and rules, as well as strategies and policies of marketization and internationalization. Yet other than the commonalities at a macro level, in these three areas concerning higher education there are some remarkable differences and disparities, such as the actual paths of size expansion, the growth and fate of private institutions, the conception of internationalization, due to different historical paths, national agendas and socio-political environments. Along this comparative approach, there are three common issues that need further elaborate discussions, namely, the unbalanced structure of quantitative development, centralized decentralization, and internationalization at home.
\end{abstract}

Keywords: Expansion, Marketization, Internationalization, Higher Education

\section{Introduction}

There are four universal driving factors that have underpinned the development of higher education community from the 1990s, namely, the formation of knowledge-based economy, the correspondingly increasing demand for more human resources with qualifications of higher education, and the dilemma between the demand for more seats at universities and university's lack of capacity to accommodate due to amounting fiscal pressure, as well as information science and technological advances in operating academic activities. Essentially the forces noted above point to quantitative side and qualitative side in the quest for a better development of higher education and a need of balance in between them, and this is particularly true of developing countries. Since the early 1990s, China and Malaysia have demonstrated their own efforts on the part of the developing world, to meet the foregoing challenges so as to work out their ambitious blueprints. To better illustrate this big picture, this article attempts to define and compare the main changes of higher education in the two countries mainly from the 1990s onwards, and differences and similarities would be equally highlighted and referred to here.

Between China and Malaysia, a great many elements are similar to each other and have close historical and socio-ethnic connections. Thus, issues regarding Malaysian-born Chinese and Chinese immigrants are usually the main topics either for the Chinese studies in Malaysia or for the Malaysian studies in China. Since the beginning of Sino-Malaysian diplomatic relation in 1974, researchers have shown more interest in areas of bilateral political and economic ties. In recent years, as higher education systems have gone through remarkable changes in the two countries, researchers began to discuss more over such topics about higher education as educational governance [1-3], history of education [4, 5], educational privatization $[6,7]$, cross-border education [8-11], educational policies [12-14]. As programs of student exchange between Malaysia and China increase, there have been a number of 
empirical researches on the visiting students' experiences in particular [15-17]. And yet the scarcity of Sino-Malaysia comparative study of higher education is clear, especially very little has been found in the literature that develops a comparative view of higher education changes over the past two decades across the two countries.

\section{Comparing China and Malaysia: A Framework}

For research on higher education, which might be often bound by the constraints of national thinking, a comparative perspective is especially valuable because academic institutions worldwide stem from common traditions, and the issues facing higher education around the world have many common characteristics [18]. In this connection, higher education researches with a comparative perspective are workable and significant by nature. However, whether the comparative approach applies well with cases of China and Malaysia and how, require a focused structure that is composed of comparability, key dimensions and appropriate comparative methods. This structure follows two major steps in the shaping of a comparison, first, making certain that the objects to compare are of the same or similar kind; second, working out the key dimensions to compare, which need a specific comparative method.

\subsection{Comparability}

As Chapman and Sarvi suggest [19], any analysis of higher education issues across East and Southeast Asia must be treated with a lot of caution for the amazing disparities and vast complexities among the countries in this region. Therefore, the question of comparability is to be considered first. Between China and Malaysia there is geographical proximity, other than this it is the bilateral relations that draw them even closer ever since the early 1970s when Malaysia became the first ASEAN country to go seeking for diplomatic relations with China. Under the "One Belt One Road" initiative, Sino-Malaysian relations are more tightened in politics, commerce and culture. In recent years people mobility at tertiary level between Malaysia and China has gained more driving force from their agreement for mutual recognition in higher education qualifications. All the foregoing factors make a comparison of higher education development between the two countries plausible and meaningful.

\subsection{Key Dimensions}

Other than what is between China and Malaysia, there has been remarkable similarity across the whole Asian region in the issues that higher education systems now confront and in the main strategies national governments are using to address those issues [20]. As an Asian Development Bank's study of 2011 suggested, continuous expansion of student population size, a tremendous increase of tertiary aged cohort and the evolution of economies to be more knowledge-intensified, innovation-motivated, led to such important common issues of higher education across Asia as capacity building, ownership and financial sources diversification, and governance reforms. These issues actually entail three macro dimensions in examining the current landscape and future prospects of higher education in the region, namely quantity, operational systems, and quality control that is more a good reflection of an international integration of higher education. Asian countries of today, particularly those emerging market economies, are planning and promoting international integration as the first priority of higher education reform agenda other than seats offering, mainly for enhancing the quality of higher education. Thus, this internationalization strategy has subsequently topped the list of strategies of institutions of higher education in general [20]. All together the three dimensions taken from the study of Asian Development Bank (ADB) are to be used for a comparative understanding of higher education changes in China and Malaysia from the early 1990s onwards, because a lot of dynamics of higher education under the three dimensions have had profound theoretical reflections and actual practices in these two emerging economies.

\subsection{Bereday's Method}

George Bereday's comparative method in education is composed of area studies and comparative studies, the former dealing with an individual country or region, and the latter being in the second place to be concerned with more than two countries or regions [21]. He further divides the area studies into descriptive and interpretative phases, and comparative studies into juxtaposition and actual comparison. Bereday's method will be used in here, for it has a more feasible pattern of doing educational comparison, which also needs to fit in the particularities of this study.

Description will be done through an extensive and in-depth collecting and reviewing of relevant documents from libraries and online databases. For interpretative work that follows, the main contexts over the past few decades are covered first, and then deep historical, socio-economic influences examined. Both tabular and textual juxtapositions would be used to work out points of comparison and the central hypothesis under the common issues of higher education in Asia referred to by ADB. Comparison would then be completed. At this stage, balanced comparison [22] would be favored, namely, information from Malaysia will be matched and discussed simultaneously with comparable information from China in consecutive paragraphs. However, when balanced comparison is not useable because of insufficiency of information, illustrative comparison would come to be applied, that is educational practices in the countries in question would be drawn at random as illustrations for the comparative points.

\section{The Quantitative Development of Higher Education}

\subsection{Expanded Access to Universities}

The socio-economic reforms from 1978 through the 1990s 
in China resulted in not only a good economic growth but also a universal understanding of the importance of human resources, as well as a more common belief about the role of education as the main road to realize one's individual aspirations. These factors made possible a fast and fabulous growth of higher education in this period. However, China began by a lower participation rate between $2 \%-3 \%$ in the 1980 s, and in 2001 it achieved a rate of $13 \%$. China was still far left behind by Malaysia that recorded $28 \%$ and a great many other countries in the same year [23]. Nevertheless, three years later China's tertiary participation rate reached $19 \%$ [24]. In 2015 approximately 2900 higher education institutions in China accommodated about 37 million students with a gross participation rate of $40 \%$ [25]. This striking achievement went on to make the Chinese government set even more ambitious target, that by 2019 and onwards the tertiary participation rate across the country will reach $50 \%$ or beyond [25].

After having gained its national sovereignty in the late 1950 s, Malaysia came to take education as a fundamental way to realize the national unification and industrialization. Basic education was developed tremendously. For example, in 1990 the enrollment rate at lower secondary schooling reached $83 \%$, and for upper secondary level it was a dissatisfactory 50 percent, and in 2004 the figure arose to $75 \%$ already [26]. Higher attendance at basic education prepared a broader talent pool of well-deserving applicants for Malaysian universities. To meet the fast growth of graduates from high schools, the number of tertiary institutions in Malaysia increased remarkably, from the establishment of University of Malaya in Kuala Lumpur in 1961 to totally three hundred higher education institutions established in all the states and the Federal Territory by 1995 . Besides, all these institutions followed government directives to enhance their capacity to accommodate more enrollments. Higher education participation rate (17-24-year cohort) in Malaysia reached 36\% [26] in 2007 and 40\% [27] in 2011 respectively. There has been an even more ambitious goal stated in the Malaysian National Higher Education Strategic Plan Beyond 2020, which stipulates a participation rate close to $50 \%$ by 2020 [28].

\subsection{Diversified Structure of Higher Education}

Expansion brings with it increased differentiation [18]. This structural differentiation in China and Malaysia can be more understood from the emergence of some non-traditional postsecondary institutions and an accelerated growth of private institutions as well. In 2000, community colleges were established in Malaysia by direct order from the Federal government, to provide alternative vocational skill training and re-educational programs for secondary school leavers and the population of working people. Besides, a number of public-financed polytechnics were built to offer industrially-oriented programs to meet the demands of semi-professionals in engineering, commerce and services sectors. By 2008 Malaysia had 24 public polytechnics and 37 public community colleges in all 13 states, with the exception of the Federal Territory [29]. The ultimate aim for community colleges development is to have one such life-long learning institution in every parliamentary district in Malaysia.

The idea of community college and the actual operation of it has been largely a local governmental effort in China. The first waves of a community college movement in China were seen in Shanghai in the mid-1990s by setting up of a number of these junior colleges for working people and adults to attend in their spare time, and later more colleges of this sort were established in other parts of the country. With the development of community colleges, a large open university system devoted to long-distance teaching and learning was built up as well with the bulk of it found at the Xian level. In general, these postsecondary institutions for life-long learning, offering non-degree award courses, have multiplied in number since the 1990s and now count in thousands.

Likewise, since 1980 when Jiu Weishan College, the first non-governmental institution of postsecondary education was established in Hunan Province, upon entering the $21^{\text {st }}$ century, the number of institutions of private ownership had increased tremendously in China, under incentive measures of the central authorities to help to relieve the growing demand pressure on the public higher education. By 1999, the number of private institutions in China bounced up to 1,270 [30], with a few prominent ones, like Huanghe $\mathrm{S} \& \mathrm{~T}$ University in Zhengzhou, Xi'an International University in Xi'an, and the number of registered students at private institutions reached 1.49 million [31]. The arising private sector has been defined as complementary to public higher education in this country after all. Despite this, by 2014 in China there were 456 private institutions with the standing to offer degrees, including 9 branch campuses of foreign universities, with a student population approaching 6 million [32].

From the time of independence up to the 1980s, in Malaysia, private higher education institutions had been under restraints. It was not until the 1990s that private sector began to increase fast especially after it was officially endorsed by the Federal government to initiate collaborative courses and programs with foreign universities. And over the years, with far expanded size, private higher education in Malaysia has moved from being an education demand-absorber to a major player on the stage of national higher education [33]. Currently some of the private universities in Malaysia, like SEGi University, Tunku Abdul Rahman University College, Taylor's University, INTI International University College, are not only prosperous in the localities, but also enjoying remarkable international reputation with their academic diplomas and degrees widely accepted in many other countries and regions in the world.

\section{The Operation of Higher Education}

\subsection{Ownership}

As the foregoing parts suggest, China and Malaysia saw private institutions of higher education spring up over the past years. This structural change deserves to be called growth of 
higher education with non-public ownership. In the arena of higher education, practically privatization occurs not only when there have emerged institutions of non-public ownership, but also when the public sector begins searching for non-governmental sources of funding. In both China and Malaysia, the diversity of financial sources has been one significant feature of the public universities.

Other than the general prosperity, private institutions of higher education and public ones in Malaysia have gone through reformations in many aspects from the 1990s. Finance is always a pivotal area of change in this context. With the Universities and University Colleges (Amendment) Act of 1996, public universities in Malaysia were corporatized, entitled to seeking non-government incomes. They have respective companies in the form of spin-offs or holdings, to generate sustainable non-governmental sources of income. Thus, non-government income from commercial consultancies, contracted researches, sales of expert services and other market-related activities are now part of the revenue system for many Malaysian public universities, although the proportion is still small [34].

The privatization of public higher education in China can be found in two forms: the operation of independent colleges and the seeking for non-governmental resources including student tuitions. In 1989, public institutions of higher education in China started to charge students tuition fees and other fees, and the rates varied according to costs of different fields of study. Also, revenues of public universities are added increasingly through the market-oriented activities in the programs of continued education and a growing number of designated commercial research projects. The independent colleges, categorized into private provider of education, made their first appearance in 1999 in China and count currently about 300 in total number, are owned and managed by private parties and yet linked to public universities [30]. The wide emergence of these affiliated colleges in China indicates some new type of ownership and new operation pattern of public higher education.

\subsection{Governance}

With privatization, higher education is supposed to enjoy more autonomy, namely, with private ownership or increasing incomes from certain non-governmental sources, a higher education institution accordingly has more say on its own affairs. On the part of government, privatization then will be functional in making public universities more adaptive to the changing environment and become increasingly self-accounted.

When this trend of privatization or entrepreneurialism was becoming more prominent in Chinese higher education from the late 1990s, the existing hierarchical structure of higher education was altered to respond to it. Public universities in China have been granted different degrees of power to pursue their own agenda, with a few elite universities of national importance exercising even more power. With the shift of power from the nation state to institutions, there has been a devolution of some of the authority from the center to the regions, as provincial governments offer an ever-increasing proportion of the public finance to institutions of higher education located in their administrative regions, and thus are expected to exert more influence on the localized development of higher education.

It looks similar that since the early 1990s, when neoliberalism was infiltrating into the public arena, corporate managerialism with performance-driven culture has become an increasingly evident feature in corporatized universities in Malaysia [35]. While allowed to exercise market-related income-generating activities and self-regulation power, Malaysian public universities in corporatization were granted some degree of autonomy in areas of institutional governance, financial management and human resource management. In academic fields of priority, student and staff management at Malaysian public universities, which were long intervened by the Federal government, more self-regulation and self-accountability are exercised. Especially the designated five research universities, like the University of Malaya, the National University of Malaysia, are reported to have full autonomy status even.

\subsection{National-level Regulatory Framework}

In China the great changes in ownership and governance of higher education since the early 1990s were associated with several directives on higher education reform enacted by Chinese state authorities. The main sprits of these directives were later translated into lines of national laws of education regarding the collection and redistribution of resources and power. For instance, the Opinions on Accelerating the Reform and Development of Higher Education, 1992 stipulated a decentralized system of higher education governance, with the central government exercising macro-management, and institutions granted more autonomy to manage themselves [36]. The Chinese Education Reform and Development Compendium of 1993 allowed for fee-charging activities for public higher education and introduced a cost-sharing notion and mechanism among the public universities then. All these initiatives were reflected in a Higher Education Law, 1998, which endorsed a lot of activities of privatization and decentralization of higher education.

Similarly, in the 1990s, between 1996 and 1997 in particular, the Malaysian Parliament passed on five pieces of legislation in order to provide national-level frameworks to endorse and regulate a privatized and decentralized higher education system for both private sector and public sector [37]. The Education Act (Amendment) of 1996 defined that private sector is part of national higher education of Malaysia and accordingly the Malaysia nation state has supremacy over all matters of private higher education. The Universities and University Colleges (Amendment) Act, 1996 allowed the diversified sources of income for Malaysian public universities and set down for the first time a concept of corporatization at public universities with revenues diversification topping the list of relevant practices of it. The Private Higher Education Act, 1996 was especially designed and implemented as the strict state parameter covering all the 
aspects of running private higher education. This act is not only for Malaysian institutions but also the branches set up by overseas universities. These two acts underpin privatization and decentralization of higher education in Malaysia in deed. Corresponding to all the law definitions above, the National Council on Higher Education Act was passed in 1996, so that a nation state-led organization of full authority can be installed to make sure about proper implementation of the laws for public sector and private sector in the future.

All together, these national laws of the 1990s pertaining to notions and mechanisms of privatization and decentralization of higher education, were enacted to develop Malaysia into an education hub in the Asia-Pacific region, and have been an inevitable part of Vision 2020 action plan to strive for Malaysia's future status as a fully developed country [38].

\section{The Qualitative Development of Higher Education}

\subsection{China: Towards a Leading Power of Higher Education}

From the late 1970s China began to show its interest in learning from western higher education. This trend was much strengthened by the directive of 1978 to amplify the western-oriented overseas education and training sponsored by Chinese government scholarships. The subsequent long-time outflux of Chinese people to have their education and training or research in western countries marked the beginning of China to become one of the major student sending countries in the world. From 1978 to 2012, about 2.65 million Chinese in total went to study outside Mainland China [39]. The year of 2014 saw about 46 thousand Chinese who left Mainland to have their tertiary education in foreign places, an increase of $11 \%$ since 2013 [40]. Besides this massive outflow of Chinese for further education outside China, the borrowing of advanced elements into China's universities by means of establishing cross-border cooperative relationships, offering chairs to non-Chinese academics etc., has been another increasingly common aspect of this country as a major education importer in the world since the 1980s.

As China is striving for the realization of China Dream from 2012 onwards, a student sender and a main education importer may be only part of the map, this country is shaping and consolidating its position as an emerging contender at regional and global student markets, a host country of tertiary students, eventually a leading power of higher education in the world. In 2014, about 38 thousand international students were studying in China, a 5.8\% increase over 2013 [40]. More than 700 higher education institutions were authorized to receive foreign students. This inbound student mobility from overseas gained its prominence recently along with China's increasing interest in program mobility and institution mobility outbound. The outbound outreach of Chinese higher education is found mainly in two forms, one is the establishment of Confucius Institutes by Chinese universities for promoting Chinese language and culture abroad. By 2017 a total of 516 Confucius Institutes and 1,076 Confucius Classrooms have been set up through the joint efforts of the Chinese government and Chinese universities in 142 countries and regions [41]; the other is the establishment of overseas campuses of some prestigious Chinese universities for academic degree education, like Lao Soochow University in 2011, a Florence campus of Tongji University in 2014, a Malaysian campus of Xiamen University in 2016 and the latest operation of a UK campus of Peking University in 2018.

In recent years in the policy context of "Double First-class" initiative of university education at either national level or provincial level, Chinese universities have commonly taken internationalization as the their more strategic work, by which more brilliant students, a larger number of internationally renowned academics, more advanced elements of education will be drawn in from overseas to help with the overall institutional capacity building of the universities.

\subsection{Malaysia: Towards a Regional Education Hub}

Since 1991 when Mohamad Mahathir's paper, entitled "Malaysia: The Way Forward" was accepted to lead the country in a new way to achieve full industrialization by 2020 , the two words of the paper - - "education hub", have emerged in the new frameworks of national development that followed, as a core concept regarding Malaysian educational aspiration. By this vision of education hub, Malaysia equipped itself with a dual-track path to realize as an education importer and an education exporter as well in the long run.

From the 1990s, there has been continuous importation of educational services from the UK, the USA, Australia and other western countries through various forms of bilateral or multilateral collaboration. As a result, internationally-linked tertiary programs were enormously available at universities and colleges in Malaysia. The cross-border higher education programs involving British and Malaysian institutions is a typical example. For historical reasons, the Malaysia-UK relationship has been the longest and more sustainable among all Malaysian foreign educational relationships. A survey conducted between 2010 to 2011 revealed that by that period of time there had been 239 transnational programs offered by 78 Malaysian institutions of higher education in collaboration with 35 UK institutions [8]. By this importing of overseas higher education services, from twinning programs, credit transfer programs, and franchised programs to Malaysia-based campuses of foreign universities, Malaysia has turned itself into a renowned regional student hub [42] for both international students and Malaysians themselves. Students from all over the world, the neighboring countries in particular, plus those from the Muslim areas of Africa, are attracted to Malaysia to pursue their further studies for either Malaysian degrees or western degrees yet at a lower cost.

Parallel to this growing importation of overseas education, since the 1990s, Malaysian universities, private ones especially, have begun exporting Malaysian education to the outside world. Exemplary ones include Limkokwing University of Creative Technology (LUCT) and Asia Pacific Institute of Information Technology (APITT). LUCT had a first establishment of a campus in London, UK, then began 
developing its branches in Southeast Asia (mostly in Indonesia and Cambodia) and in Africa (mainly in Botswana, Lesotho and Swaziland). APIIT is another Malaysian institution that has crossed the nation's border to deliver its courses to other peoples. Having had a traditional focus on IT education, Malaysia-based APIIT has already spread its academic influence over the South Asian region with the establishment of campuses in Sri Lanka, Pakistan and India.

Responding to the call for qualitative monitoring over private higher education as it multiplied in the number of institution and in the amount of education exportation activities, in 1996 Malaysia had the National Accreditation Board Act passed to stipulate the general academic criteria that laid the foundation of a quality assurance system of private sector of higher education in this country, and later this act helped develop a Malaysian Qualifications Framework that functions as an instrument of higher education quality management with an ultimate objective of integrating Malaysian universities, public and private, into an international community of higher education.

\section{Major Findings}

\subsection{Massification}

Over the last two decades in China and Malaysia, fast economic growth and ambitious national human resource planning have provided great momentum for continuous size expansion of higher education. Since the 1990s, the two countries experienced a similar movement from elite to mass access of higher education, and both are currently striving for universal access. This process was largely reinforced by a growing size of private provision of higher education. However, this structural change regarding higher education has a far more profound picture in Malaysia, as student seats at public universities in this country are in constant shortage.

From the 1970s, out of the New Economic Policy, the Malaysian government used a quota system to designate a proportion of university seats close to $60 \%$ to $80 \%$ to Malays in the name of affirmative action to help Malays improve in all aspects of their social life. The rest little quota had to be shared by hundreds of thousands non-Malay students, who were then forced to seek their opportunity of further education in the non-public institutions of higher education. This had been encouraged by the Federal government, hence the fabulous growth of private sector of higher education in Malaysia since the late 1980s. This quantitative development of higher education in Malaysia demonstrated a story of Malay primacy, and has led to a defining feature of current Malaysian higher education structuring, namely, public sector is always Malay-dominant, while private sector is open to all applicants, including foreigners. Therefore, in Malaysia one concrete fact about the structure of the massified higher education is that the private sector outnumbers the public one a lot either in institutions or in registered students.

While it has been more racially driven in Malaysia, the quantitative development of higher education in China was most about satisfying the ever-increasing demands for human resources with postsecondary education qualifications. Instead of catering to the private provision of postsecondary education, the Chinese government chose to enhance the capacity of accommodating increasing student enrollments at the public sector through either establishing new universities and colleges, or by frequent institutional mergers. Under the preference of the government, private provision in China, from the very beginning, was taken only as a complement to the more prestigious and important public universities, with little strategic planning and supporting policies of government. Contrastingly, with gloomy prospects and little confidence of students it is no surprise that private provision of higher education in China has been decreasing in size, which is now left far behind by the public sector. This has set the tune for private higher education development in China for many years to come.

Another shared concurrence regarding the structural changes of higher education in Malaysia and China is that life-time education for adults was planned and practiced to meet the complex demands of the modern population. This is reflected in the wide emergence of community colleges, open universities, continuing education programs, and distance learning programs in both countries. However, in Malaysia this kind of postsecondary education supply is mainly stipulated and managed by the Federal government, while in China it is only a matter of local educational enterprise.

\subsection{Marketization}

To meet the increasing student demand for more access to higher education and meanwhile to ease the amounting public fiscal pressure, funding diversification and resource privatization were taken as the main mechanisms functional in the two countries' higher education systems. This in turn has led to further size expansion of private provision and more privatization of public sector from the 1990s onwards in China and Malaysia.

However, as mentioned previously, in China, private institutions are regarded only as a complement to the public sector, standing in an inferior position when it comes to strategy, financial support, as well as quality control at both national and provincial levels. The Private Education Law, 2005 actually does not help to change but enhance this status. Contrastingly, private sector has grown to be the much larger part of national higher education of Malaysia in terms of size, as seats at Malaysian public universities are still more reserved for Malays even after the abolishment of quota system. Actually, the private sector is leading Malaysia to the universal access of higher education and is playing a more strategic part in the infrastructure building of regional hub of education. Consequently, there has been clear obligation for the nation state to steer, support and control over quantity and quality issues for private institutions, as demonstrated in the foregoing Federal acts concerning higher education and the so-called "ministerialization" principle exercised from top down, in which Malaysian minister of higher education takes full care of the key areas of private higher education operation, 
like institution establishment, curricula designing, instruction language [38].

Along all the practices about diversification and privatization in Malaysia and China, there has been a common trend of decentralization of higher education, which enables greater flexibility and adaptability of universities in these changing contexts. With all these relevant notions and realities, a growing sense of being more flexible and adaptable for universities to deal with changing environment, underpins an essential conception of marketization of higher education in deed.

In Malaysia, the trend of decentralization grew out of corporatization at public universities initiated in the 1990s. Likewise in China, issues concerning revenues diversification were put on the pressing agenda of public higher education reform, and subsequently more autonomy has been granted by the state to public universities in some key areas of internal governance, so as to better respond to the changes outside. The infiltration of neoliberalism and key principles of new public management into government operation since the 1990s could offer the common theoretical ground and rationale for current higher education marketization in these two countries. Nevertheless, a notable distinction with the practice of decentralization in the Chinese context is that the Chinese government has also devolved some higher education jurisdiction power to the provincial level, hence a central-provincial-institutional engagement in deed, while in Malaysia it is just a power shift from the federal authorities to institutional structure because of the federal constitutional dictation that education in Malaysia is all under the direct jurisdiction of the Federal government.

\subsection{Internationalization}

Along student participation at the tertiary level approaching $50 \%$, China and Malaysia are showing an increasing concern over the qualitative aspect of higher education development, driven by their ambitious national strategic plans to build up their position as leaders in the Asia Pacific region and beyond in the fields of science, technology and education. In this transforming process, internationalization has been regarded as a more underpinning factor for capacity building of higher education.

Concerning the typology of internationalizing higher education, generally inbound internationalization and outbound one fall into the classification [43]. In terms of inbound internationalization, Malaysia and China are still ranked at the top of the education importers list and as two major student senders in the world, however from the aspect of outbound internationalization, the two countries are changing into competitive education exporters in the Asia Pacific region and beyond. And from the first decade of the $21^{\text {st }}$ century especially, to be one major exporter of higher education has taken the lead under the vision of education hub for Malaysia and the vision of a strong power of higher education for China respectively. To be more specific, by importing more advanced elements from overseas, from branch campus of foreign university to recruitment of internationally renowned academics to curricular or program cooperations, China and Malaysia are sharpening the edges to be competitive exporter of higher education. This kind of development of transnational higher education has been labeled as exportation driven by importation [44].

At the institutional level, where the real process of internationalization takes place [45], generally organizational activities in Malaysian universities and Chinese universities also have quite similar reflections in commitment-making and infrastructure building in ad hoc units and regular financial support system. Various academic activities, such as internationalization of curricula, student and staff mobility inbound and outbound, twinning programs, credit transfer programs, external degree programs as well as institution mobility in the form of branch campus have had equally important treatment, in which Malaysia universities claim an earlier start and have relatively more matured system.

Additionally, internationalization of higher education in Malaysia falls in dual tracks. Private universities and university colleges in Malaysia are more internationalized compared with the public institutions in that they always take a much larger proportion of international students at the undergraduate level. At the postgraduate level, however it is the public universities that are far more internationalized by having a very international composition of students, so is the same with scientific research, whose internationally-linked programs outnumber the private universities a lot. Quite unlike this internationalization differentiation claim between the private sector and the public sector in Malaysia, in China public institutions of higher education have been the sole practioners of internationalization, while private institutions, preoccupied with their struggle for survival, hardly have had the capability to join in the process.

\section{Concluding Remarks}

From the foregoing thematic descriptions and discussions, it can be understood that for both Chinese and Malaysians, it is mainly the two interconnected educational imperatives, namely access and excellence, which have underlain their higher education efforts over the last three decades. While considerations with quantitative development were dominant in the 1990s, the pursuit of more excellence has become overwhelming for the present and the upcoming future. So, the historical logic within this overall development of higher education in China and Malaysia is a progression from quantity to quality, with internal or external rules of educational marketization introduced to equip higher education systems with more autonomy, self-accountability and efficiency so as to help reach the designed ends. Generally, about higher education, China and Malaysia have a range of common issues that deserve further discussions.

First, there has been clear imbalance regarding the growth of higher education in the two countries. In China, it is the many inequalities for the private providers of higher education in the policy setting, incentives from government, as well as the disrespectful treatment from the society, hence the 
decreasing size of private sector and a shrinking confidence in the people who run and manage these private institutions. In Malaysia, however, the imbalance lies in the composition of faculty and students at public universities, which shows a dominating proportion of Malays. This unbalanced structure of the population at public sector of higher education in Malaysia remains largely unchanged, due to the race-based "Malay Supremacy" that keeps as the only philosophy of Malaysian authorities.

Secondly, as those rules or principles involving some market mechanisms work in higher education, theoretically, there will be a greater degree of academic autonomy and a shift of state's role from tight control to loosened supervision as the resources have more diversified channels other than governmental allocations. However, either in Malaysia or in China, the operation of higher education has not shown a substantial change away from the past status, because under the national strategies asking for better educational excellence, the nation state affords an even larger part of the cost of public higher education through varied forms or plans of public financing, especially from the late 1990s, whereby the government can still exert its overwhelming influence over the running of higher education system.

It is for this reason that public universities in Malaysia are under "centralized decentralization" [46], not yet free from the "shackles of bureaucratic regulation" [34]. A very similar situation of closer state control through more financial investments can be found in China, as the Chinese government pours even more financial resources into higher education, it can keep a few universities of national importance under a structure of greater central planning and scrutiny. And at provincial level, it is a similar picture that local institutions with more public resources and financial allocation are seem to be under more top-down planning and managing. This kind of operation of higher education in China has been labeled as "imitative market-driven governance" with the core idea of using market rules for practice yet on the basis of government planning [47].

Thirdly, as one prevalent theme in internationalization literature of recent years, internationalization at home (IaH) has been considered as inevitable and even more pivotal, compared with internationalization abroad, in the building of a country of higher education excellence, because it is about a process of international and intercultural dimensions being fully and actively integrated into a campus life, not limited to curriculum but for every other aspect that collects to form an internationalized whole of the institution. The very importance of internationalization at home was already acknowledged early in 2011 in a Malaysian federal policy statement of internationalization policy of higher education, which called for a more harmonious integration of international students into their Malaysian campus life and their Malaysian neighborhood. Thus, the more specific task for Malaysian universities is the finding of practical ways to make internationalization at home function better. However, this seems to be a far more challenging work for Chinese higher education, as internationalization at home was introduced only in recent years by some farsighted academic to be a new direction of developing higher education in China [48]. Public universities in China unanimously are much more concerned with the numerical growth of international students and faculty members than with the question whether these foreign people have had a good blending or integration into their academic lectures, research projects and everyday life in a Chinese campus with their Chinese classmates and colleagues, let alone a consideration of a scheme of internationalization at home.

\section{Acknowledgements}

This article is part of a High-Level Talent Start-Up Research Project of Liupanshui Normal University (Grant Number: LPSSYKYJJ202103).

\section{References}

[1] Sobia, A. \& Hussin, S. (2012). University governance: trends and models. Kuala Lumpur: University of Malaya Press.

[2] Norzaini, A. (2012). Malaysian public universities governance system: a compromise between collegiality, autonomy and corporate management approaches. International Journal of Knowledge, Culture and Change Management. 11 (5): 115-134.

[3] Wang, X. J. (2015). Governance reforms of public universities in Malaysia. Studies in Foreign Education. 42 (12): 57-66.

[4] Lian, J. J. (2005). A comparative study of higher education in Malaysia and the Philippines. Fuzhou: Fujian Renmin Press.

[5] Hayhoe, R. (1989). China's universities and the open door. Toronto: OISE Press.

[6] Zhang, S. (2004). Privatization of higher education: study on the demand for minban higher education by high school students in Mainland China. Ph. D. thesis. Hong Kong: The Chinese University of Hong Kong.

[7] Wang, X. J. (2014). Research on the privatization of Malaysian higher education. Chongqing Higher Education Research. 2 (3): 101-104.

[8] Hill, C., K. C., Leong, C. Y. C. \& Rozilini, F. C. (2014). TNE Trans-national education or tensions between national and external? A case study of Malaysia. Studies in Higher Education. 39 (6): 952-966.

[9] Li, M. (2006). Cross-border higher education of mainland Chinese students: Hong Kong and Macao in a globalizing market. Ph. D. thesis. Hong Kong: University of Hong Kong.

[10] Li. J. (2015). Internationalization of higher education in Malaysia. M. A. thesis. Ningbo: Ningbo University.

[11] Li, J. and Chen, L. (2015). Internationalization of higher education in Malaysia: A localized concept analysis. Journal of Ningbo University (Education Edition). 37 (3): 32-37.

[12] Hayhoe R., Li, J., Lin, J. \& Zha, Q. (eds.). (2011). Portraits of 21 st century Chinese universities: In the move to mass higher education. Hong Kong \& Dordrecht: Comparative Education Research Centre, The University of Hong Kong \& Springer. 
[13] Zhong, H. Q. and Wang, X. J. (eds.). (2012). Higher education policies and regulations in Malaysia. Guilin: Guangxi Norman University Press.

[14] Selvaraj, G., Krishnan, K. and Azlin, N. M. (2014). Current trends in Malaysian higher education and the effect on education policy and practice: An overview. International Journal of Higher Education. 3 (1): 85-93.

[15] Zhang, Y. and Chen, W. S. (2012). Factors influencing Chinese students to study in Malaysian private higher educational institutions: A cross-sectional survey. SEGi Review. 5 (1): 123-131.

[16] Zhang, J. (2015). Cross-cultural adaptation of Malaysian students in Beijing. M. A. thesis. Beijing: Beijing Foreign Studies University.

[17] Low, H. H., Yang, H. J. \& Yeoh, C. L. (2015). Studying in Malaysia public universities: Choice decision of Mainland Chinese students. In F. L. Gaol (ed.). Interdisciplinary behavior and social sciences. Leiden: CRC Press, 249-253.

[18] Altbach, P. G. \& Peterson, P. M. (1999). Introduction. In P. G. Altbach and P. M. Peterson (eds.). Higher education in the 21st Century: Global challenge and national response, 1-2. Annapolis Junction, MD: IIE Books, 1, 9.

[19] Chapman, D. and Sarvi, J. (2016). Widely recognized problems, controversial solutions: issues and strategies for higher education development in East and Southeast Asia. In K. H. Mok (ed.). Managing international connectivity, diversity of learning and changing labor markets: East Asian perspectives. Singapore: Springer, 26.

[20] Asian Development Bank (ADB) (2011). Higher education across Asia: An overview of issues and strategies. Manila: Asian Development Bank, 5, 5.

[21] Bereday, G. (1964). Comparative method in education. New York: Holt, Rinehart and Winston, 10-28.

[22] Bereday, G. (1969). Reflections on comparative methodology in education, 1964-1966. In M. A. Eckstein and H. J. Noah (eds.). Scientific investigations in comparative education, 3-24. London: Collier-Macmillan Limited, 10.

[23] UNESCO (2003). Education for all global monitoring report 2003-4: Gender and education for all. Paris: UNESCO.

[24] Zhou, Ji. (2004). Educational work in the view of scientific development.

http://www.moe.gov.cn/publicfiles/business/htmlfiles/moe/cm smedia/document/410.doc. (accessed 6 March, 2021).

[25] Ministry of Education. (2015a). Quality report of higher education in China: Gross participation rate reached $40 \%$. http://www.gov.cn/xinwen/2016-04/07/content_5062041.htm. (accessed 6 March, 2021).

[26] Arokiasamy, L. and Ong, S. F. (2008). The roles of private higher educational institutions in promoting formal lifelong education in Malaysia. The Journal of International Social Research. 1 (4): 77-88.

[27] Wong, B. R. (2013). Performance measurement in higher education: A Malaysian scenario. paper presented at QS-MAPLE. Johannesburg, South Africa. Kuala Lumpur: International University of Malaya-Wales. http://www.qsmaple.org/3rdqsmaple/download/powerpoints/. (accessed 12 December, 2020).
[28] UNESCO (2015). UNESCO science report: towards 2030 Paris: UNESCO, 685.

[29] Tierney, W. and Morshidi, S. (2008) Challenges facing Malaysian higher education. International Higher Education. 53: $23-24$

[30] Cao, Y. X. and Levy, D. (2005). China's private higher education: the impact of public-sector privatization. International Higher Education. 41: 14-15.

[31] National Center for Education Development Research. (2001). Green Paper on Education in China Annual Report on Policies of China's Education. Beijing: Education Science Publishing House, 134.

[32] Ministry of Education. (2015b). Statistics of national education development in 2014. Beijing: MOE.

[33] Loh, R. (2012). Private higher education in Malaysia: Access, internationalization and quality assurance. Master's Thesis. Melbourne: RMIT University, 4.

[34] Morshidi, S. (2006). Malaysia. In UNESCO (ed.). Higher education in South-East Asia. Bangkok: UNESCO, 112, 111.

[35] Lee, M. N. N. (2004) Restructuring Higher education in Malaysia. School of Educational Studies. Pulau Pinang: Universiti Sains Malaysia, 69.

[36] Morgan, W. J. and Li, F. (2015). Education: from egalitarian ideology to public policy. in S. G. Goodman (ed). Handbook of the politics of China. Glos: Edward Elgar Publishing Ltd, 217-237.

[37] Mukherjee, H. and Wong, P. K. (2011). The National University of Singapore and the University of Malaya: Common Roots and Different Paths. In P. G. Altbach and J. Salmi (eds.). The Road to academic excellence: the making of world-class research universities. Washington DC: The International Bank for Reconstruction and Development / The World Bank, 129-166.

[38] Tan, A. M. (2002). Malaysian private higher education: Globalization, privatization, transformation and marketplaces. London: ASEAN Academic Press.

[39] Shao, W. (2013). National priorities in the internationalization of higher education - recent development and future trend in China. Brussels. http://www.unica-network.eu. (accessed 2 April, 2021).

[40] Department of Education and Training. (2016). Chinaoutbound and inbound international students. Canberra: DET, Australian Government. https://internationaleducation.gov.au/. (accessed 3 August, 2016).

[41] Xinhua. Over 500 Confucius Institutes founded in 142 countries, regions.

http://www.xinhuanet.com/english/2017-10/07/c_136663278.ht m. (accessed 4 April, 2021).

[42] Knight, J. and Morshidi, S. (2011). The complexities and challenges of regional education hubs: Focus on Malaysia. Higher Education. 62: 593-606.

[43] Ye, L, Wang, Z. T. (2018) China higher education internationalization: a stock take of current activity. International and Comparative Education. (5): 43-52.

[44] Zheng, H. R. \& Guo, L. J. (2014). Quality control of transnational higher education: a comparison among the importers. (6): 43-49. 
[45] Knight. J. (2004). Internationalization remodeled: Definition, approaches, and rationales. Journal of Studies in International Education. 8 (1): 5-31.

[46] Lee, M. N. N. (2006). Centralized decentralization in Malaysian education. In C. Bjork (ed.). Educational decentralization: Asian experiences and conceptual contributions. Dordrecht: Springer, 149-158.
[47] Zhang, Y. Q. \& Zhang, H. Z. (2018). From Imitative Market-driven Governance to Quasi-market-driven Governance: The Direction of Higher Education Governance Change in China. Journal of Higher Education. 39 (6): 3-19.

[48] Zhang, W. \& Liu, B. C. (2017). Internationalization at home: new trend of higher education in China. University Education Science. 163 (3): 10-17. 